\title{
Pengaruh Gaya Kepemimpinan Kepemimpinan dan Penempatan Pegawai Terhadap Motivasi Kerja Serta Dampaknya Pada Kinerja Pegawai di Biro Umum Setda Provinsi Jambi
}

\author{
M. Zahari MS ${ }^{1}$, Fakhrul Rozi Yamali ${ }^{2}$, A. Irfani ${ }^{3}$ \\ 1,2,3 Magister Manajemen, Fakultas Ekonomi, Universitas Batang Hari \\ Jl. Slamet Riyadi no.1, RT.09, Sungai Putri, Danau Tlk, Kota Jambi 361222 \\ Correspondence email: ahmad26faiz@gmail.com
}

\begin{abstract}
Theoretically outlined, Employee Performance can be influenced by several variables including Leadership Style, Placement, and Work Motivation. Therefore, the performance of employees at the General Bureau of Setda Jambi Province can also be attributed to these three variables, this is what inspired the authors to conduct the research. Research objectives: 1. To find out the description of leadership style, placement, motivation, and performance of Employees in the General Bureau of Setda Jambi Province, 2. To know the direct and indirect influence of leadership style and placement on the work motivation of employees in the General Bureau of Setda Jambi Province, 3. To know the direct and indirect influence of leadership style and placement on the performance of Employees in the General Bureau of Setda Jambi Province, 4. To know the influence of leadership style and placement through work motivation on Kinerja Employees in The General Bureau of Setda Jambi Province. This research that became the object of the research was employees of the General Bureau of Setda Jambi Province with a population of 130 people who were used as a research sample. Analysis techniques using Path Analysis tool using SPSS 22 software. The results showed that: 1. Leadership style, placement, motivation and employee performance are in good condition, 2. Leadership and placement styles directly and indirectly affect employee motivation, 3. Leadership and placement styles directly and indirectly affect employee performance, 4. Leadership and placement styles through motivation directly and indirectly affect performance.
\end{abstract}

Keywords: Leadership Style, Placement, and Work Motivation

\section{Pendahuluan}

Peradaban manusia sekarang ini segala aspek kehidupan tidak lepas dari berorganisasi, karena pada kodratnya manusia merupakan makhluk sosial yang cenderung untuk selalu hidup bermasyarakat. Hal ini nampak baik di dalam kehidupan rumah tangga, organisasi kemasyarakatan, terlebih pada saat seseorang memasuki dunia kerja. Seseorang tersebut akan berinteraksi dan masuk menjadi bagian dalam organisasi tempatnya bekerja. Organisasi dalam mencapai tujuannya, setiap organisasi memerlukan sumber daya untuk mencapainya. Sumber daya itu antara lain sumber daya alam, finansial, ilmu pengetahuan dan teknologi, serta sumber daya manusia. Sumber daya manusia merupakan aset organisasi yang paling penting, dan membuat sumber daya organisasi lainnya menjadi bekerja. Dengan demikian, tanpa sumber daya manusia sumber daya lainnya akan menganggur dan kurang bermanfaat dalam mencapai tujuan organisasi. Sumber daya manusia merupakan sebuah mitra yang turut menentukan tumbuh dan berkembangnya suatu organisasi. Sehubungan dengan hal itu maka klasifikasi dan mutu sumber daya manusia menentukan mutu pelayanan, citra dan kepercayaan yang secara langsung ikut mempengaruhi tingkat profesionalisme yang berlanjut pada tingkat partisipasi dan sumbangsih terhadap keberhasilan suatu organisasi baik pemerintah maupun swasta dalam mencapai tujuannya. Manusia berprilaku melakukan sesuatu karena adanya faktor penggerak dari dalam manusia itu sendiri atau yang lebih dikenal dengan istilah motif.

Biro Umum Setda Provinsi Jambi merupakan suatu Birokrasi Sekretariat Daerah Provinsi Jambi yang saling berhubungn dengan Birokrasi lain guna membantu Sekretaris Daerah dalam menjalankan roda Pemerintahan di Provinsi Jambi. Oleh karena itu, berhasil atau tidaknya suatu Birokrasi sudah pasti ditentukan oleh kualitas pimpinannya, karena kedudukan pemimpin sangat mendominasi semua aktivitas yang dilakukan. Gaya kepemimpinan yang baik mendorong bawahan untuk mengungkapkan dan merespon berbagai kesulitan yang dihadapinya, terutama di lingkungan kerjanya, Bawahan bekerja selalu tergantung pada pimpinan di dalam suatu birokrasi pemerintahan, Bila pimpinan tidak memiliki kemampuan dalam memimpin suatu organisasi, maka tugas-tugas yang sangat kompleks tidak dapat dikerjakan dengan baik. Kepemimpinan didefinisikan sebagai kemampuan untuk mempengaruhi, menggerakkan dan mengarahkan suatu tindakan pada diri seorang atau kelompok orang untuk mencapai tujuan tertentu pada situasi tertentu (Asnawi, 2011). Kemampuan mempengaruhi akan menentukan cara yang digunakan karyawan dalam mencapai suatu kinerja. 
M. Zahari MS et al, Pengaruh Gaya Kepemimpinan Kepemimpinan dan Penempatan Pegawai Terhadap Motivasi Kerja Serta Dampaknya Pada Kinerja Pegawai di Biro Umum Setda Provinsi Jambi

Tabel. 1

Jumlah Pegawai Biro Umum Setda Provinsi Jambi Tahun 2015-2019

\begin{tabular}{|c|c|c|c|}
\hline Tahun & Jumlah Staf & Unsur Pimpinan & Tota \\
\hline 2015 & 101 & 13 & 114 \\
\hline 2016 & 106 & 13 & 119 \\
\hline 2017 & 103 & 13 & 116 \\
\hline 2018 & 100 & 13 & 113 \\
\hline 2019 & 117 & 13 & 130 \\
\hline
\end{tabular}

Sumber : Tata Usaha Biro Umum Setda Provinsi Jambi

Selanjutnya, Penempatan pegawai juga menjadi salah satu variabel faktor pendorong terbentuknya kinerja. Karena Setiap intansi harus dapat memilih dan menentukan pegawai yang berkompeten untuk mengisi suatu jabatan agar tugas pokok pada jabatan tersebut dapat dilaksanakan. Untuk itu harus diperoleh pekerja yang memiliki kemampuan sesuai dengan jabatan yang akan menjadi tanggung jawabnya dengan kata lain calon yang ditempatkan harus memiliki kompetensi yang diperlukan untuk dapat melaksanakan pekerjaan dalam suatu jabatan secara efektif dan efisien.

Tabel 2

Jenis Jabatan pada Biro Umum Tahun 2019 Menurut Penempatannya

\begin{tabular}{|c|c|c|c|}
\hline Jenis Jabatan & Kualisifiłkasi Pendidikan & Kualisifikasi Pendidikan Yang menjabat & Semai dengan hualisifikasi pendidikan \\
\hline $\begin{array}{l}\text { 1. Ka. Biro Umum Setda } \\
\text { Provinsi }\end{array}$ & $\begin{array}{l}\text { S2 Ilmu Pemerintahan, S2 Ilmu Administrasi } \\
\text { Negara, S2Ilmu Sosial, S2 Manajemen SDM }\end{array}$ & S1 Ilmo Sosial & Tidak \\
\hline 2. Kabag Pelayanan Umum. & $\begin{array}{l}\text { Sl ilmu hukum/Akuntasi/Manajemen/ } \\
\text { Administrasi Pemerintah. }\end{array}$ & S2 Administrasi Poblik & $\mathrm{Ya}$ \\
\hline 3. Kabag Rumah Tangga. & $\begin{array}{l}\text { S1 ilmu hulkum/Akuntasi/Manajemen/ } \\
\text { Administrasi Pemerintah. }\end{array}$ & S1 Ilmu Sosial & $\mathrm{Ya}$ \\
\hline $\begin{array}{l}\text { 4. Kabag Administrasi } \\
\text { Kevangan. }\end{array}$ & $\begin{array}{l}\text { S1 ilmu Ekonomi/Manajemen/ } \\
\text { Administrasi Pemerintahan }\end{array}$ & S2 Ilmu Marajemen Kevangan & $\mathrm{Ya}$ \\
\hline 5. Ka. TÜ Biro. & $\begin{array}{l}\text { S1 lmu hokum/Akuntasi/Manajemen/ } \\
\text { Administrasi/Pemerintah. }\end{array}$ & S2 Hukvm & $\mathrm{Ya}$ \\
\hline 6. Kasub. Logistik. & $\begin{array}{l}\text { S1 ilmu Ekonomi/Manajemen' } \\
\text { Administrasi Pemerintahan }\end{array}$ & S1 Ilmu Ekomomi & $\mathrm{Ya}$ \\
\hline 7. Kasub. Perjalanan Diras & $\begin{array}{l}\text { S1 ilmu Ekonomi/Manajemen/ } \\
\text { Administrasi Pemerinahan. }\end{array}$ & S1 Ilmu Sosial & $\mathrm{Ya}$ \\
\hline 8. Ka. TU Pimpinan. & $\begin{array}{l}\text { S1 lmu hukvm/Akuntasi/Manajemen/ } \\
\text { Administrasi / Pemerintah. }\end{array}$ & S1 Ilmu Pemerintahan & Ya \\
\hline 9. Kasub. Operasional. & $\begin{array}{l}\text { S1 ilmu holkum/Akuntasi/Manajemen' } \\
\text { Administrasi Pemerintah }\end{array}$ & S2 Manajemen & $\mathrm{Ya}_{\mathrm{a}}$ \\
\hline 10. Kasub. Penata Keuangan. & $\begin{array}{l}\text { S1 ilmu Ekonomi/Manajemen/ } \\
\text { Administrasi Pemerintahan }\end{array}$ & S1 Ilmu hoikum & Tidak \\
\hline 11. Kasub. Pelayanan Umum. & $\begin{array}{l}\text { S1 ilmu hulkum/Akvntasi/Manajemen/ } \\
\text { Administrasi Pemerintah. }\end{array}$ & S1 Ilmu Ekonomi & $\mathrm{Ya}$ \\
\hline 12.Kasub. Rumah Tangga. & $\begin{array}{l}\text { S1 ilmu hulkum/Akuntasi/Manajemen/ } \\
\text { Administrasi Pemerintah. }\end{array}$ & S2 Administrasi Poblik & $\mathrm{Ya}$ \\
\hline $\begin{array}{l}\text { 13.Kasub. Administrasi Belanja } \\
\text { Pegawai }\end{array}$ & $\begin{array}{l}\text { S1 ilmu Ekonomi/Manajemen } \\
\text { /Administrasi/Pemerintahan }\end{array}$ & S1 Ilmu hukum & Tidak \\
\hline
\end{tabular}

Sumber : Tata Usaha Biro Umum Setda Provinsi Jambi

Selanjutnya salah satu faktor yang tidak kalah pentingnya dalam meningkatkan Kinerja pegawai adalah Motivasi Kerja . Motivasi merupakan salah satu faktor penting dalam mendorong seorang karyawan untuk bekerja. Motivasi adalah kesediaan individu untuk mengeluarkan upaya yang tinggi untuk mencapai tujuan organisasi (Stephen, 2001).

Ada tiga elemen kunci dalam motivasi yaitu upaya, tujuan organisasi dan kebutuhan. Upaya merupakan ukuran intensitas. Bila seseorang termotivasi maka ia akan berupaya sekuat tenaga untuk mencapai tujuan, namun belum tentu upaya yang tinggi akan menghasilkan kinerja yang tinggi. Oleh karena itu, diperlukan intensitas dan kualitas dari upaya tersebut serta difokuskan pada tujuan organisasi. Kebutuhan adalah kondisi internal yang menimbulkan dorongan, dimana kebutuhan yang tidak terpuaskan akan menimbulkan tegangan yang merangsang dorongan dari dalam diri individu. Dorongan ini menimbulkan perilaku pencarian untuk menemukan tujuan, tertentu. Apabila ternyata terjadi pemenuhan kebutuhan, maka akan terjadi pengurangan tegangan. Pada dasarnya, karyawan yang termotivasi berada dalam kondisi tegang dan berupaya mengurangi ketegangan dengan mengeluarkan upaya. 
M. Zahari MS et al, Pengaruh Gaya Kepemimpinan Kepemimpinan dan Penempatan Pegawai Terhadap Motivasi Kerja Serta Dampaknya Pada Kinerja Pegawai di Biro Umum Setda Provinsi Jambi

Tabel 3

Tunjangan Penghasilan Pegawai Di Biro Umum Setda Provinsi Jambi Tahun 2019

\begin{tabular}{llc}
\hline No & \multicolumn{1}{c}{ Jabatan } & Jumlah TPP (RP) \\
\hline 1. & Kepala Biro Umum Setda Provinsi Jambi (Eselon II b) & 15.000 .000 \\
2. & Kepala Bagian Biro Umum Setda Provinsi Jambi (Eselon III a) & 10.000 .000 \\
3. & Kepala Sub Bagian Biro Umum Setda Provinsi Jambi (Eselon IV a) & 6.000 .000 \\
4. & Staf Fungsional (Gol III a - Gol III b) & $2.200 .000-2.800 .000$
\end{tabular}

Sumber : Tata Usaha Biro Umum Setda Provinsi Jambi

Selanjutnya menurut Rivai (2004) Kinerja merupakan perilaku yang nyata yang ditampilkan setiap orang sebagai prestasi kerja yang dihasilkan oleh karyawan sesuai dengan perannya dalam perusahaan.

Tabel 4

Capaian Keberhasilan Pelaksanaan Kegiatan Pada Biro Umum Setda Provinsi Jambi Tahun 2019

\begin{tabular}{|c|c|c|c|c|}
\hline No & $\begin{array}{l}\text { Bidang Urusan Pemerintahan } \\
\text { Daerah dan Program/Kegiatan }\end{array}$ & $\begin{array}{l}\text { Indikator Kinerja Program } \\
\text { (Out come)/Kegiatan (output)) }\end{array}$ & Kinerja Yang di Capai & $\begin{array}{c}\text { Capaian Kinerja dan Anggaran Renja SKPD } \\
\text { Tahun berjalan yang dievaluasi } 2019(\%)\end{array}$ \\
\hline 1 & $\begin{array}{l}\text { Program Pelayanan Administrasi } \\
\text { Perkantoran }\end{array}$ & $\begin{array}{l}\text { Tingkat pemenuhan kebutuhan dasar } \\
\text { opera sional unit kerja dalam mend dkung } \\
\text { tugas pokok dan fungsinya }\end{array}$ & 20.728 .247 .582 & 96,16 \\
\hline 2 & $\begin{array}{l}\text { Kegiatan Penyediaan Jasa Surat } \\
\text { Menyurat }\end{array}$ & Jumlah surat masulk/keluar pertahun & 60.184 .000 & 97,13 \\
\hline 3 & $\begin{array}{l}\text { Kegiatan Penyediaan Jasa } \\
\text { Komunikasi, Sumberdaya Air dan } \\
\text { Listrik }\end{array}$ & $\begin{array}{l}\text { Persentase pembayaran komunikasi, } \\
\text { sumberdaya air dan listrik yang } \\
\text { difasilitas }\end{array}$ & 4.848 .234 .996 & 99,24 \\
\hline 4 & $\begin{array}{l}\text { Kegiatan Penyediaan Bahan Logistik } \\
\text { Kantor }\end{array}$ & $\begin{array}{l}\text { Persentase Bahan Logistik Kantor yanag } \\
\text { difalitasi }\end{array}$ & 1.670 .233 .000 & 99,50 \\
\hline 5 & $\begin{array}{l}\text { Kegiatan Rapat-rapat koordinasi dan } \\
\text { konsultasi keluar daerah }\end{array}$ & $\begin{array}{l}\text { Jumlah Rapat Koordinasi dan Konsultasi } \\
\text { Keluar Daerah }\end{array}$ & 3.659 .357 .500 & 96,98 \\
\hline 6 & $\begin{array}{l}\text { Kegiatan Rapat-rapat koordinasi dan } \\
\text { konsultasi kedalam daerah }\end{array}$ & $\begin{array}{l}\text { Jumlah Rapat Koordinasi dan Konsultasi } \\
\text { Kedalam Daerah }\end{array}$ & 1.812 .239 .940 & 99,98 \\
\hline \multicolumn{2}{|c|}{ Jumlah } & 100 & 32.778 .497 .018 & 98,165 \\
\hline
\end{tabular}

Sumber : Tata Usaha Biro Umum

Secara teoritis sebagaimana diuraikan diatas, kinerja pegawai dapat dipengaruhi oleh beberapa variabelvariabel diantaranya adalah gaya kepemimpinan, penempatan, dan motivasi kerja. Oleh karena itu, kinerja pegawai pada biro umum setda provinsi jambi tentunya juga dapat dikaitkan dengan ketiga faktor tersebut. Tujuan penelitian ini adalah untuk mengetahui pengaruh gaya kepemimpinan $(x 1)$ dan penempatan pegawai $(x 2)$ terhadap motivasi kerja (y) serta dampaknya pada kinerja pegawai (z) di biro umum setda provinsi jambi. tujuan penelitian ini adalah untuk mengetahui mengetahui pengaruh gaya kepemimpinan dan penempatan melalui motivasi kerja terhadap kinerja pegawai di biro umum setda provinsi jambi.

\section{Tinjauan Teori}

\section{Indikator Gaya Kepemimpinan}

Indikator-indikator Gaya Kepemimpinan adalah sebagai berikut:

1. Kepemimpinan secara suportif (Supportive leadership), digambarkan sebagai pemimpin yang menunjukkan perhatian besar kepada kesejateraan dan pemenuhan kebutuhan bawahan. Perilaku dengan gaya ini bersifat terbuka, bersahabat, dan dapat didekati dengan mudah.

2. Kepemimpinan yang direktif (Directive leadership), digambarkan sebagai pemimpin yang menunjukkan dominasi dalam mengarahkan, mengawasi dan mengatur bawahan secara ketat. Perilaku pemimpin ini lebih banyak membuat perencanaan, membuat jadwal kerja dan menetapkan tujuan kinerja dan standar perilaku bawahan, serta menekankan pada pemenuhan terhadap aturan dan peraturan yang ada dalam organisasi.

3. Kepemimpinan partisipatif (Partisipative leadership), digambarkan lebih banyak mengkonsultasikan dan mendiskusikan pada bawahan sebelum membuat keputusan dan banyak berdikusi dengan bawahan di tempat kerja.

4. Kepemimpinan berorientasi prestasi (Achievement-oriented leadership), digambarkan sebagai pemimpin dengan tujuan yang jelas dan mempunyai tantangan yang besar terhadap bawahannya. Perilaku pemimpin ini juga percaya kepada bawahannya dan memberikan bimbingan kepada mereka untuk mencapai tujuan yang tinggi.

\section{Indikator Penempatan Pegawai}

1. Pendidikan

Penempatan karyawan menyangkut beberapa indikator dari penempatan pegawai itu sendiri yaitu :

a. Pendidikan yang seharusnya, artinya pendidikan yang harus dijalankan syarat 
b. Pendidikan alternatif, yaitu pendidikan lain apabila terpaksa, dengan tambahan latihan tertentu dapat mengisi syarat pendidikan yang seharusnya.

2. Pengetahuan kerja, pengetahuan yang harus dimiliki oleh seorang tenaga kerja agar dapat melakukan kerja dengan wajar. Pengalaman kerja ini sebelum ditempatkan dan harus diperoleh pada ia bekerja dalam pekerjaan tersebut. Indikatornya adalah pengetahuan mendasari keterampilan, peralatan kerja. , prosedur pekerjaan, metode proses pekerjaan.

3. Keterampilan kerja, kecakapan/keahlian untuk melakukan suatu pekerjaan yang hanya diperoleh dalam praktek. Indikator keterampilan kerja adalah (a) keterampilan mental, seperti menganalisa data, membuat keputusan, menghitung, menghafal, dan lain-lain, (b) keterampilan fisik, dapat bertahan lama dengan pekerjaan yang dikerjakannya; dan (c) keterampilan sosial, seperti mempengaruhi orang lain, berpidato, dan lainnya.

4. Pengalaman kerja, pengalaman seseorang tenaga kerja untuk melakukan pekerjaan tertentu. Pengalaman pekerjaan ini indikatornya adalah (a) lama waktu/masa kerja; (b) tingkat pengetahuan dan keterampilan yang dimiliki; dan (c) penguasaan terhadap pekerjaan dan peralatan.

\section{Indikator Motivasi Kerja}

Menurut Mangkunegara (2009) terdapat pola motivasi yang menonjol:

1. Kebutuhan untuk berprestasi (Need of achievement), merupakan kebutuhan untuk mencapai sukses, yang diukur berdasarkan standar kesempatan dalam diri seseorang.Kebutuhan ini berhubungan erat dengan pekerjaan dan mengarahkan tingkah laku pada usaha untuk mencapai prestasi tertentu.

2. Kebutuhan berafiliasi (Need for affiliation), merupakan kebutuhan akan kehangatan dan sokongan dalam hubungannya dengan orang lain. Kebutuhan ini mengarahkan tingkah laku untuk mengadakan hubungan secara akrab dengan orang lain.

3. Kebutuhan kekuatan (Need for power), merupakan kebutuhan untuk menguasai dan mempengaruhi situasi dan orang lain agar menjadi dominan dan pengontrol. Kebutuhan ini menyebabkan orang yang bersangkutan kurang memperdulikan perasaan orang lain.

\section{Indikator Kinerja}

Dalam menilai dan mengevaluasi kinerja dapat ditinjau dari beberapa indikator. Indikator untuk mengukur tingkat kinerja pegawai antara lain (PP No. 49 Tahun 2011) adalah Sasaran kerja pegawai dan prilaku kerja.

\section{Hipotesis}

Hipotesis 1: gaya kepemimpinan, penempatan, motivasi dan Kinerja pegawai di Biro Umum Setda Provinsi Jambi diduga berada dalam kondisi baik.

Hipotesis 2: gaya kepemimpinan, dan penempatan diduga berpengaruh langsung dan tidak langsung terhadap motivasi pegawai di Biro Umum Setda Provinsi Jambi.

Hipotesis 3: gaya kepemimpinan, dan penempatan diduga berpengaruh langsung dan tidak langsung terhadap kinerja pegawai di Biro Umum Setda Provinsi Jambi.

Hipotesis 4: gaya kepemimpinan dan penempatan melalui motivasi diduga berpengaruh terhadap kinerja pegawai di Biro Umum Setda Provinsi Jambi.

\section{Metode}

\section{Uji Hipotesis}

\section{Koefisien Determinasi $\left(R^{2}\right)$}

Koefisien determinasi (KD) pada intinya mengukur seberapa jauh kemampuan model dalam menerangkan variasi variabel terikat. Nilai koefisien determinasi adalah dari nol (0) dan satu (1), nilai $\mathrm{r}^{2}$ yang kecil berarti kemampuan variabel-variabel independent dalam menjelaskan variasi variabel dependent amat terbatas. Nilai yang mendekati satu berarti variabel-variabel independent memberikan hampir semua informasi yang dibutuhkan untuk memprediksikan variasi variabel dependent. Analisis Koefisien determinasi (KD) digunakan untuk melihat seberapa besar variabel independent $(\mathrm{X})$ berpengaruh terhadap variabel dependent $(\mathrm{Y})$ yang dinyatakan dalam persentase.

\section{Uji t (Parsial)}

Pengujian ini bertujuan untuk menguji apakah masing-masing variabel bebas berpengaruh secara signifikan terhadap variabel terikat secara parsial dengan $\alpha=0,05$ dan juga penerimaan atau penolakan hipotesis. Uji parsial (Uji t) untuk menjawab hipotesis dua, tiga, lima, enam dan delapan. Uji ini digunakan untuk mengetahui pengaruh variabel bebas (independent variable) terhadap variabel terikat (dependent variable) secara parsial. Pengujian ini dilakukan dengan membandingkan $t_{\text {hitung }}$ dengan $t_{t a b e l}$ pada derajat kesalahan 5\%. Apabila nilai $t_{\text {hitung }}>t_{t a b e l}$, maka variabel 
bebasnya (independent variable) memberi pengaruh yang signifikan terhadap variabel terikat (Y). Sebaliknya Apabila nilai $t_{\text {hitung }}<\mathrm{t}_{\text {tabel, }}$, maka variabel bebasnya $(\mathrm{X})$ tidak memberi pengaruh yang signifikan terhadap variabel terikat $(\mathrm{Y})$. Kriteria dari pengujian hipotesis secara parsial pada tingkat signifikansi 0,05 (5\%) adalah sebagai berikut:

- Apabila $\mathrm{t}_{\text {hitung }}>\mathrm{t}_{\text {tabel }}$ atau alpha $<0.05$, maka tolak $\mathrm{H}_{0}$ dan terima $\mathrm{H}_{1}$.

- Apabila $\mathrm{t}_{\text {hitung }}<\mathrm{t}_{\text {tabel }}$ atau alpha $>0.05$, maka terima $\mathrm{H}_{0}$ dan tolak $\mathrm{H}_{1}$

\section{Uji F (Simultan)}

Uji F dilakukan untuk melihat apakah model regresi dapat digunakan untuk memprediksi variabel dependen. Tingkat probabilitas < 0,05 dianggap signifikan atau model regresi tersebut dapat digunakan untuk memprediksi variabel dependen.

\section{Intervening}

Pengujian hipotesis mediasi dapat dilakukan dengan prosedur yang dikembangkan oleh sobel dan dikenal dengan uji Sobel (Sobel test). Uji sobel dilakukan dengan cara menguji kekuatan pengaruh tidak langsung X ke Y lewat $M$. Pengaruh tidak langsung $X$ ke $Y$ lewat $M$ dihitung dengan cara mengalikan jalur $X \rightarrow M$ (a) dengan jalur $M$ $\rightarrow \mathrm{Y}(\mathrm{b})$ atau $\mathrm{ab}$. Jadi koefisien $\mathrm{ab}=\left(\mathrm{c}-\mathrm{c}^{\prime}\right)$, dimana $\mathrm{c}$ adalah pegaruh $\mathrm{X}$ terhadap $\mathrm{Y}$ tanpa mengontrol $\mathrm{M}$, sedangkan c' adalah koefisien pengaruh $\mathrm{X}$ terhadap $\mathrm{Y}$ setelah mengontrol $\mathrm{M}$. Standard error koefisien a dan $\mathrm{b}$ di tulis dengan $\mathrm{s}_{\mathrm{a}}$ dan $\mathrm{s}_{\mathrm{b}}$ dan besarnya standard error pengaruh tidak langsung (indirect effect) adalah $\mathrm{s}_{\mathrm{ab}}$.

\section{Hasil \\ Pengujian hipotesis satu (deskriptif), Gaya Kepemimpinan, Penempatan, Motivasi dan Kinerja Pegawai Pada Biro Umum Setda Provinsi Jambi Berada pada kondisi baik. \\ Untuk menjawab hipotesis pertama digunakan hipotesis deskriptif dengan skala likert, variabel yang disajikan dalam penelitian ini adalah gaya kepemimpinan, penempatan, motivasi dan kinerja pegawai pada Biro Umum Setda Provinsi Jambi, berikut adalah jumlah skor masing masing variabel dan dapat dikategorikan dengan rentang skala masing masing variabel dalam penelitian ini : \\ - Variabel gaya kepemimpinan dengan jumlah skor total 4480, jika dilihat dari rentang skala, hal ini menunjukkan bahwa gaya kepemimpinan pada Biro Umum dalam kategori baik. \\ - Variabel penempatan dengan jumlah skor total 4394, jika dilihat dari rentang skala, hal ini menunjukkan bahwa penempatan pada Biro Umum Setda Provinsi Jambi dalam kategori baik. \\ - Variabel motivasi dengan jumlah skor total 5198, jika dilihat dari rentang skala, hal ini menunjukkan bahwa motivasi pegawai pada Biro Umum Setda Provinsi Jambi dalam kategori baik. \\ - Variabel kinerja pegawai dengan jumlah skor total 7172, jika dilihat dari rentang skala, hal ini menunjukkan bahwa kinerja pegawai pada Biro Umum Setda Provinsi Jambi dalam kategori baik. \\ Poin-poin di atas dapat ditarik kesimpulan bahwa hipotesis I yakni kondisi gaya kepemimpinan, penempatan, motivasi serta kinerja pegawai Biro Umum Setda Provinsi Jambi masih dalam kategori baik.}

\section{Pengujian hipotesis ke dua pengaruh Gaya Kepemimpinan dan Penempatan Secara Langsung dan Tidak Langsung Terhadap Motivasi pegawai pada Biro Umum Setda Provinsi Jambi}

Pengujian hipotesis ke dua akan diuji dengan uji $\mathrm{F}$ (simultan) sesuai dengan paradigma yang mencerminkan hipotesis yaitu " gaya kepemimpinan dan penempatan secara bersama-sama berpengaruh positif terhadap motivasi pegawai pada Biro Umum Setda Provinsi Jambi”. hipotesis diterima. Hal ini terlihat pada tabel SPSS dibawah ini dimana F-hitung > F-tabel maka gaya kepemimpinan dan penempatan berpengaruh signifikan terhadap motivasi

Struktur II model persamaan regresi pengaruh Gaya Kepemimpinan dan Penempatan Pegawai terhadap Motivasi kerja karyawan sebagai berikut: $\mathrm{Y}=\mathrm{P}_{\mathrm{X} 1 \mathrm{Y}} \mathrm{X}_{1}+\mathrm{P}_{\mathrm{X} 2 \mathrm{Y}}$. $\mathrm{X}_{2}+\mathrm{e}$

Pengaruh Gaya Kepemimpinan dan Penempatan Pegawai secara simultan terhadap Motivasi kerja dapat dilihat hasil pada model summary berikut ini:

- $\quad$ Nilai koefisien determinasi (Adusted $\mathrm{R}^{2}$ ) pada kolom Adjusted R Square sebesar 0,536. Angka ini memberikan gambaran bahwa secara silmultan Gaya Kepemimpinan dan Penempatan Pegawai memiliki pengaruh sebesar 53,6 \% terhadap variasi naik turunya variabel Motivasi kerja karyawan.

- $\quad$ Nilai F hitung adalah sebesar 5,873. Hipotesis yang dapat disusun adalah sebagai berikut, Berdasarkan hasil perhitungan maka dapat dicari nilai $\mathrm{F}$ tabel dengan tingkat keyakinan sebesar $95 \%$ atau $\alpha=0,05, \mathrm{df}=\mathrm{n}-\mathrm{k}=130-2$ = 128 diperoleh nilai F tabel sebesar 1,656. Dengan demikian maka Ho di tolak dan Ha diterima, dengan kata lain ada hubungan yang linear antara variabel Gaya Kepemimpinan dan Penempatan Pegawai secara simultan dengan dengan variabel Motivasi kerja. Hal ini menunjukkan bahwa hipotesis ke II memiliki pengaruh yang positif dan signifikan. 
M. Zahari MS et al, Pengaruh Gaya Kepemimpinan Kepemimpinan dan Penempatan Pegawai Terhadap Motivasi Kerja Serta Dampaknya Pada Kinerja Pegawai di Biro Umum Setda Provinsi Jambi

\section{Pengujian Hipotesis Ke Tiga Pengaruh Gaya Kepemimpinan dan Penempatan Secara Langsung dan Tidak Langsung Terhadap Kinerja Pegawai Pada Biro Umum Setda Provinsi Jambi}

Pengujian hipotesis ke tiga akan menguji dengan uji $\mathrm{F}$ (simultan) sesuai dengan paradigma yang mencerminkan hipotesis yaitu "Gaya Kepemimpinan dan Penempatan secara bersama-sama berpengaruh positif dan siginifikan terhadap Kinerja Pegawai pada Biro Umum Setda Provinsi Jambi" hipotesis diterima. Hal ini terllihat pada tabel SPSS dibawah ini dimana F- hitung > F-tabel maka budaya organisai dan Insentif berpengaruh signifikan terhadap kinerja pegawai. Struktur III path model pengaruh Gaya Kepemimpinan dan Penempatan Pegawai terhadap Kinerja pegawai adalah sebagai berikut: $\mathrm{Z}=\mathrm{P}_{\mathrm{X} 1 \mathrm{Z}} \mathrm{X} 1+\mathrm{P}_{\mathrm{X} 2 \mathrm{Z}} \mathrm{X} 2+\mathrm{e}$

Pengaruh Gaya kepemimpinan dan Penempatan terhadap Kinerja pegawai dapat dilihat hasil nilai koefisien determinasi (Adusted $\mathrm{R}^{2}$ ) pada kolom Adjusted R Square sebesar 0,537. Angka ini memberikan gambaran bahwa secara gabungan Supervisi Kepemimpinan dan Budaya Organisasi karyawan memiliki pengaruh sebesar 53,7\% terhadap baik turunnya kondisi Kinerja pegawai pada Biro Umum Setda Provinsi Jambi, sementara sisanya sebesar 46,3\% dipengaruhi oleh variabel lainnya yang tidak dimasukkan dalam model penelitian. Untuk mengukur linear tidaknya hubungan Supervisi Kepemimpinan dan Budaya Organisasi dengan Produktivitas karyawan digunakan uji F (lihat Sarwono, 2007), yaitu membandingkan antara F hitung dan F tabel. F hitung diperoleh dari hasil pengujian berikut nilai $\mathrm{F}$ hitung sebesar 7,76 selanjutnya hipotesis yang dapat disusun adalah sebagai berikut, $\mathrm{F}$ tabel dengan tingkat keyakinan sebesar $95 \%, \mathrm{df}=\mathrm{n}-\mathrm{k}=130-2=128$ diperoleh nilai $\mathrm{F}$ tabel sebesar 1,656. Dengan demikian maka Ho di tolak dan Ha diterima, dengan kata lain ada hubungan yang linear antara Gaya Kepemimpinan dan Penempatan Pegawai secara simultan dengan dengan variabel Kinerja . Hal ini menunjukkan bahwa pada hipotesis ke III memiliki pengaruh yang positif dan signifikan.

\section{Pengujian Hipotesis ke Empat Pengaruh Gaya Kepemimpinan dan Penempatan melalui Motivasi diduga berpengaruh langsung dan tidak langsung terhadap Kinerja pegawai di Biro Umum Setda Provinsi Jambi}

Pengujian hipotesis ke empat akan diuji dengan uji t sesuai dengan paradigma yang mencerminkan hipotesis yaitu " motivasi berpengaruh positif dan signifikan terhadap kinerja pegawai pada Biro Umum Setda Provinsi Jambi" hipotesis diterima. Hal ini terllihat pada tabel SPSS dibawah ini dimana t- hitung $>\mathrm{t}$-tabel maka motivasi berpengaruh signifikan terhadap kinerja pegawai. Struktur IV model persamaan regresi pengaruh Gaya Kepemimpinan dan Penempatan serta Motivasi terhadap Kinerja pegawai sebagai berikut: $\mathrm{Z}=\mathrm{P}_{\mathrm{X} 1 \mathrm{Z}} \mathrm{X} 1+\mathrm{P}_{\mathrm{X} 2 \mathrm{Z}} \mathrm{X} 2+\mathrm{P}_{\mathrm{YZ}} \mathrm{Y}+\mathrm{e}$

Pengaruh Gaya Kepemimpinan dan Penempatan serta Motivasi kerja terhadap Kinerja pegawai dapat dilihat hasil pada model summary yaitu nilai koefisien determinasi (Adusted $\mathrm{R}^{2}$ ) pada kolom Adjusted $\mathrm{R}$ Square sebesar 0,78. Angka ini memberikan gambaran bahwa secara gabungan Gaya Kepemimpinan dan Penempatan serta Motivasi terhadap Kinerja Pegawai memiliki pengaruh sebesar $78 \%$, sementara sisanya sebesar $22 \%$ dipengaruhi oleh variabel lainnya yang tidak dimasukkan dalam model penelitian. Nilai F hitung sebesar 146,9 selanjutnya hipotesis yang dapat disusun adalah sebagai berikut, $\mathrm{F}$ tabel dengan tingkat keyakinan sebesar $95 \%, \mathrm{df}=\mathrm{n}-\mathrm{k}=130-2=128$ diperoleh nilai $\mathrm{F}$ tabel sebesar 1,656. Dengan demikian maka Ho di tolak dan Ha diterima, dengan kata lain ada hubungan yang linear antara Gaya Kepemimpinan, Penempatan Pegawai dan Motivasi kerja terhadap Kinerja Pegawai . Hal ini menunjukkan hipotesis ke IV memiliki pengaruh dapat diterima.

\section{Analisa Deskriptif (Gambaran X1, X2, Y dan Z) Gaya Kepemimpinan}

Hasil penelitian deskriptif didapat gaya kepemimpinan pada Biro Umum Setda Provinsi Jambi berada pada kategori baik, hal ini dapat dilihat dengan jumlah skor dalam questioner gaya kepemimpinan yaitu 4282 skor yang masih dalam kategori baik, hal ini berarti gaya kepemimpinan pada Biro Umum Setda Provinsi Jambi mempunyai sudah baik. Hal tersebut sesuai dengan teori yang dikemukakan oleh Rivai (2014) yang menyatakan gaya kepemimpinan adalah sekumpulan ciri yang digunakan pimpinan untuk mempengaruhi bawahan agar sasaran dari suatu organisasi tercapai. Hasil penelitian ini menunjukan bahwa adanya kesesuaian dari hasil penelitian dari Pantun dkk (2019) dengan judul Pengaruh Gaya Kepemimpinan Terhadap Kinerja Pegawai dengan Motivasi dan Disiplin kerja sebagai variabel intervening pada Dinas Pekerjaan Umum Dan Perumahan Rakyat Provinsi Jambi yang menyebutkan bahwa semakin baik gaya kepemimpinan yang dilakukan dari pemimpin akan mempengaruhi terhadap meningkatnya Kinerja pegawai.

\section{Penempatan Pegawai}

Penempatan pegawai pada Biro Umum Setda Provinsi Jambi berada pada kategori baik, hal ini dapat dilihat dari jumlah skor dalam questioner penempatan yaitu 4394 skor yang masih tergolong baik, hal ini menunjukkan bahwa penempatan yang dilakukan oleh atasan pada hal ini dapat dilihat dari jumlah skor rata-rata dalam questioner masih dalam kategori baik. Hal tersebut sesuai dengan teori yang dikemukakan oleh Siswanto (2012) yang 
menyatakan bahwa penempatan kerja adalah suatu urutan yang kronologis untuk menenmpatkan pegawai yang tepat pada posisi yang tepat. Hasil penelitian ini menunjukan bahwa adanya kesesuaian dari hasil penelitian dari Montalalu, et al (2016) yang menyebutkan bahwa semakin baik penempatan pegawai, maka semakin baik pula kinerja pegawai tersebut.

\section{Motivasi Kerja}

Motivasi pegawai pada Biro Umum Setda Provinsi Jambi memiliki motivasi yang tergolong baik, hal ini dapat dilihat dari jumlah skor rata-rata yaitu 5173 skor yang masih tergolong baik, hal ini berarti pegawai pada Biro Umum Setda Provinsi Jambi memiliki motivasi yang tinggi mempengaruhi terhadap meningkatnya kinerja pegawai.

\section{Kinerja}

Kinerja pegawai pada Biro Umum Setda Provinsi Jambi juga tergolong dalam kategori cukup baik, hal ini dapat dilihat dengan jumlah skor rata-rata yaitu 5177 skor yang tergolong cukup baik. Hal tersebut sesuai dengan teori yang dikemukakan Mangkunegara (2009) yang menyatakan bahwa kinerja adalah hasil kerja secara kualitas dan kuantitas yang dicapai seorang pegawai dalam melaksanakan tugasnnya sesuai dengan tanggung jawab yang diberikan kepadanya.

\section{Analisa Verifikatif \\ Pengaruh Gaya Kepemimpinan dan Penempatan Secara Langsung dan Tidak Langsung Terhadap Motivasi pada Biro Umum Setda Provinsi Jambi}

Hasil penelitian terdapat pengaruh langsung dan tidak langsung dari variabel gaya kepemimpinan (X1) dan penempatan (X2) terhadap motivasi (Y) pada Biro Umum Setda Provinsi Jambi). Menurut Widiantara, (2012) yang menyatakan bahwa karyawan yang ditugaskan atau ditempatkan sesuai dengan bidang pendidikan, ketrampilan, pengalaman kerja, dan minat, terlihat karyawan merasa lebih puas dan lebih senang dalam bekerja. Pimpinan dalam organisasi memiliki tanggung jawab untuk melakukan analisis dan pengamatan atas sikap dan tindakan para bawahannya dalam bekerja, dimana prestasi kerja individu pada dasarnya dipengaruhi secara langsung oleh beberapa variabel seperti individu itu sendiri, kondisi lingkungan, organisasi yang bersifat kompleks dan dengan kondisi pengalamannya. Setiap variabel tersebut mencakup beberapa indikator, seperti variabel individu, kemampuan dan keterampilan, latar belakang, sosial budaya, demografis sedangkan organisasinya seperti kebijakan umum organisasi, sistem imbalan, sistem karir maupun pola pekerjaan atau sistem pekerjaannya. Hasil penelitian ini juga sesuai dengan penelitian terdahulu yakni Pengaruh Gaya Kepemimpinan Terhadap Kinerja Pegawai dengan Motivasi dan Disiplin Kerja sebagai variabel Intervening Pada Dinas pekerjaan Umum dan Perumahan rakyat Provinsi Jambi, Pantun dkk (2019). Hal ini membuktikan bahwa gaya kepemimpinan dan penempatan mempunyai pengaruh yang sangat berarti terhadap motivasi pegawai pada Biro Umum setda Provinsi Jambi, atau semakin baik gaya kepemimpinan dan penempatan maka akan semakin tinggi motivasi pegawai pada Biro Umum Setda Provinsi Jambi. Hasil penelitian dapat dilihat pengaruh langsung maupun tidak langsung gaya kepemimpinan dan penempatan terhadap motivasi pegawai, Dengan demikian, semakin baik gaya kepemimpinan dan penempatan maka akan semakin tinggi motivasi pegawai.

\section{Pengaruh Gaya Kepemimpinan Dan Penempatan Secara Langsung dan Tidak Langsung Terhadap Kinerja Pegawai pada Biro Umum Setda Provinsi Jambi}

Hasil penelitian diketahui bahwa terdapat pengaruh langsung dan tidak langsung dari dari variabel gaya kepemimpinan (X1) dan penempatan (X2) terhadap kinerja pegawai (Z) pada Biro Umum setda Provinsi Jambi. Hasil penelitian ini juga sesuai dengan penelitian terdahulu Pantun dkk, (2019). Ini berarti gaya kepemimpinan dan penempatan mempunyai pengaruh yang sangat berarti terhadap kinerja pegawai pada Biro Umum setda provinsi Jambi, dengan demikian semakin baik gaya kepemimpinan dan penempatan maka akan semakin meningkat kinerja pegawai pada Biro Umum Setda Provinsi Jambi, Dengan demikian, semakin baik gaya kepemimpinan dan penempatan maka akan semakin baik kinerja pegawai pada Biro Umum Setda Provinsi Jambi.

\section{Pengaruh Motivasi Terhadap Kinerja Pegawai pada Biro Umum Setda Provinsi Jambi.}

Hasil penelitian diketahui bahwa terdapat pengaruh langsung dan tidak langsung dari dari variabel) motivasi terhadap kinerja, hal ini berarti motivasi $(\mathrm{Y})$ mempunyai pengaruh yang signifikan terhadap kinerja pegawai $(\mathrm{Z})$ pada Biro Umum setda Provinsi Jambi, serta dapat dilihat dari pengaruh langsung variabel motivasi terhadap kinerja pegawai yaitu sebesar 0,98 atau 98\%. Hal ini sesuai dengan teori Menurut Robbins (2003) mendefinisikan Motivasi sebagai proses yang ikut menentukan intensitas, arah, dan ketekunan individu dalam usaha mencapai sasaran. Jadi motivasi merupakan upaya yang ada dalam diri seseorang dalam memenuhi kebutuhannya guna mencapai tujuan 
organisasi. Motivasi merupakan kekuatan pendorong yang akan mewujudkan suatu perilaku guna mencapai tujuan kepuasan dirinya. Motivasi terbentuk dari sikap seseorang pegawai dalam menghadapi situasi kerja. Motivasi merupakan kondisi yang menggerakkan diri pegawai yang terarah untuk mencapai tujuan organisasi, sikap mental merupakan kondisi mental yang mendorong diri pegawai untuk berusaha mencapai prestasi kerja secara maksimal. Hasil penelitian ini menunjukan bahwa adanya kesesuaian dari hasil penelitian dari Ida Ayu (2008). Ini berarti bahwa motivasi yang tinggi pada Biro Umum Setda Provinsi Jambi dapat mempengaruhi kinerja pegawai pada Biro Umum Setda Provinsi Jambi, semakin tinggi motivasi semakin tinggi pula kinerja pegawai pada Biro Umum setda Provinsi Jambi.

\section{Pengaruh Gaya Kepemimpinan dan Penempatan melalui Motivasi Secara Simultan dan Parsial Terhadap Kinerja Pegawai pada Biro Umum Setda Provinsi Jambi}

Hasil penelitian dapat dilihat bahwa gaya kepemimpinan dan penempatan melalui motivasi secara simultan berpengaruh terhadap kinerja, pengaruh langsung sebesar $73 \%$ dan pengaruh tidak langsung sebesar 5\%, pengaruh total keseluruhan yaitu sebesar $78 \%$, hal ini membuktikan bahwa gaya kepemimpinan dan penempatan melalui motivasi berpengaruh langsung dan tidak langsung terhadap peningkatan kinerja pegawai pada Biro Umum setda Provinsi Jambi. Hal ini sesuai dengan teori Menurut Hal tersebut sesuai dengan teori yang dikemukakan oleh Mangkunegara (2009) yang menyatakan bahwa kinerja adalah hasil kerja secara kualitas dan kuantitas yang dicapai seorang pegawai dalam melaksanakan tugasnnya sesuai dengan tanggung jawab yang diberikan kepadanya. Kinerja merupakan suatu gambaran mengenai tingkat pencapaian pelaksanaan suatu kegiatan/program/kebijakan dalam mewujudkan sasaran, tujuan, misi, visi serta organisasi. Pada dasarnya pengertian kinerja berkaitan dengan tanggung jawab individu atau organisasi dalam menjalankan apa yang menjadi wewenang dan tanggung jawab yang diberikan kepadanya. Hasil penelitian ini menunjukan bahwa adanya kesesuaian dari hasil penelitian dari Pantun dkk (2019) dengan judul Pengaruh Gaya Kepemimpinan Terhadap Kinerja Pegawai dengan Motivasi dan Disiplin kerja sebagai variabel intervening pada Dinas Pekerjaan Umum Dan Perumahan Rakyat Provinsi Jambi Ini berarti gaya kepemimpinan dan penempatan pegawai melalui motivasi kerja mempunyai pengaruh langsung dan tidak langsung terhadap kinerja pegawai pada Biro Umum setda Provinsi Jambi.

\section{Simpulan}

Berdasarkan hasil penelitian dan pembahasan sebagaimana sudah diuraikan sebelumnya maka dapat disimpulkan sebagai berikut:

1 Gaya Kepemimpinan, penempatan, dan motivasi berada dalam kondisi baik, sedangkan kinerja pegawai Biro Umum Setda Provinsi Jambi berada dalam kondisi cukup baik.

2 Gaya kepemimpinan dan penempatan berpengaruh secara langsung dan tidak langsung terhadap motivasi pegawai pada Biro Umum setda Provinsi Jambi. Jumlah pengaruh langsung dan tidak langsung sebesar 53,6 \%, sementara sisanya 46, $4 \%$ dipengaruhi variabel lain yang tidak diteliti.

3 Gaya kepemimpinan dan penempatan berpengaruh secara langsung dan tidak langsung terhadap kinerja pegawai pada Biro Umum setda Provinsi Jambi. Jumlah pengaruh langsung dan tidak langsung sebesar 53,7 \%, sementara sisanya 46,3\% dipengaruhi variabel lain yang tidak diteliti.

4 Gaya kepemimpinan dan penempatan melalui motivasi secara simultan berpengaruh langsung dan tidak langsung terhadap kinerja. Jumlah pengaruh langsung dan tidak langsung sebesar 78\%, sementara sisanya $22 \%$ dipengaruhi variabel lain yang tidak diteliti.

\section{Daftar Pustaka}

Asnawi, T. 2011. Kepemimpinan. Jambi: Hamada Prima Jambi.

Brahmasari, Ida Ayu dan Agus Suprayetno. 2008. Pengaruh Motivasi Kerja, Kepemimpinan dan Budaya Organisasi Terhadap Kepuasan Kerja Karyawan serta Dampaknya pada Kinerja Perusahaan (Studi kasus pada PT. Pei Hai International Wiratama Indonesia). Jurnal Manajemen dan Kewirausahaan, 10.

Bukit, Pantun, Yamali, F.R, dan Ananda, R. 2019. Pengaruh Gaya Kepemimpinan terhadap Kinerja pegawai dengan Motivasi dan Disiplin kerja sebagai variabel intervening pada Dinas Pekerjaan Umum Dan Perumahan Rakyat Provinsi Jambi. J-MAS,4(2)

Mangkunegara, AP, 2009. Manajemen Sumber Daya Manusia. Bandung : PT. Remaja Rosdakarya.

Monolalu, Ricky, Lotje Kawet, Olivia Nelwan.2016. Pengaruh Kepribadian, Orientasi Kerja, dan Penempatan Pegawai terhadap Kinerja pegawai pada Dinas Pariwisata Provinsi Sulawesi Utara. Emba, 4(1).

Peraturan Pemerintah Republik Indonesia Nomor 46 Tahun 2011 Tentang Penilaian Prestasi Kerja Pegawai Negeri Sipil.

Robins, Stephen P. 2003. Prilaku Organisasi. Jakarta : PT. Indeks Kelompok Gramedia. 
Siswanto, Bejo. 2012. Manajemen Tenaga Kerja Indonesia. Jakarta : Aksara.

Veithzal, Rivai. 2014. Manajemen Sumber Daya Manusia untuk Perusahaan. Depok : PT. Raja Grafinfo Persada.

Widiantara, B. 2012. Pengaruh Penempatan karyawan, Kompensasi, dan kesempatan Berprestasi terhadap Semangat kerja karyawan di Yayasan Triatma Surya Jaya Bandung. Jurnal Ilmiah Manajemen dan Akuntansi STIE Triatma Mulya. 17(2) 